\title{
THE POTTSVILLE SERIES ALONG NEW RIVER, WEST VIRGINIA
}

BY DAVID WHITE

(Read before the Society December 28, 1894)

\section{CONTENTS}

Page

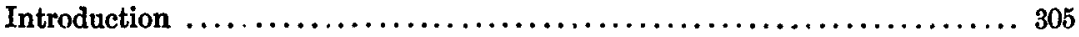

Use of term "Pottsville" and formations included in "Pottsville series".... 306

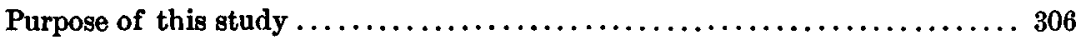

Rapid differentiation of and change in floras during Pottsville time....... 307

Stratigraphy of the series. .................................... 308

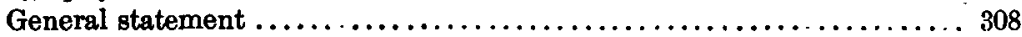

Conglomerates of Piney Creek section...................... 308

Completion of series at Nuttall and Hawks Nest . . . . . . . . . . . . 309

Number and position of coals mined on New river............... 310

Quinnimont-Fire Creek horizon........................... 310

Position of Sewell coal... .............................. 311

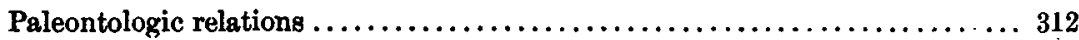

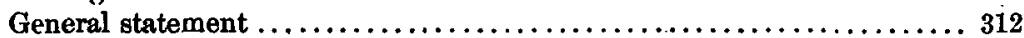

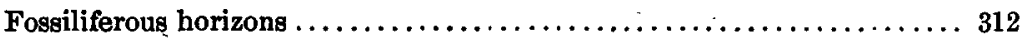

Fossil plants near the lower conglomerate on Piney creek .......... 313

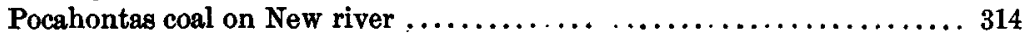

Flora of the Quinnimont-Fire Creek stage and its affinities.......... 314

Flora of the Sewell coal and its range........................... 316

Fossil plants of the "Homewood sandstone"...................... 318

Paleontologic relation of New River section to Sharon coal in Ohio..... 319

Equivalence of Pottsville sections. .............................. 319

Problem of correlation of base of Pottsville series ................... 320

\section{INTRODUCTION.}

This paper is intended to present certain general conclusions reached in the course of a preliminary study of the stratigraphy and paleontology of the Pottsville series along New river in West Virginia. While concerned mainly with paleontologic correlations, it touches incidentally 
on the stratigraphic position of the well-known New River coals mined at numerous points from Quinnimont down to Hawks Nest.

\section{Use of term "Pottsville" and Formations included in "Pottsville SERIES."}

The Pottsville series, or the "Conglomerate series," as it is perhaps better known in West Virginia, embraces the group of sandstones, conglomerates, sandy shales and coals lying between the green and red calcareous Mauch Chunk shales below, and the softer, more argillaceous terranes of the "Lower Productive Coal Measures" above. It is essentially a sandstone series, though it includes some of the most valuable soft coals of the Appalachian region. Its massive ledges, rising often abruptly at short intervals from one another, support a more or less clearly defined terrace plateau, across which for more than 30 miles the river has cut its celebrated gorge. The outcrop of the series is conformable to the general Appalachian trend. It is fringed on the east by certain high knobs northeast of Hinton, and it descends westward to the falls of the Kanawha, below which it passes under water level.

The general characters of the group in southern West Virginia have been well described by Professors W. M. Fontaine* and I. C. White. $\dagger$ To the New River section the former gave the name "Conglomerate series," so defining it as to include the lowest and the uppermost conglomerates in the Piney Creek section, he supposing the uppermost to represent the Kanawha Falls sandstone. Fontaine's Conglomerate series was in large part referred by Professor White to the "Pottsville," both authors regarding it as the equivalent of the Pottsville conglomerate, the lower boundary being drawn by the latter author at the top of the red and green shales. The reference of the entire series to the Pottsville has been made, so far as I know, almost wholly on the basis of the stratigraphic evidence, the facts being, first, that it is more or less distinctly conglomeratic, and, second, that it occupies the interval between the Lower Carboniferous marine beds and the true Lower Productive Coal Measures (XIII of the Pennsylvania geologists) of the Appalachian basin.

\section{Purpose of this Study.}

The present paper will necessarily be limited to a few somewhat generalized conclusions, resulting from a preliminary paleontologic and

* The Great Conglomerate on New River, West Virginia. Am. Jour. Scl., third series, vol. vii, 1874, pp. 459, 573. The Conglomerate Series of West Virginia. Am. Jour. Sci., third series, vol. $x i$, 1876, pp. 276, 374 .

† Bull. U. S. Geological Survey, no. 65, 1888, p. 179 et seq. 
stratigraphic examination of the New River section, made in order to ascertain the general relations of the major divisions of the series there, together with the contained coals, to the Pottsville series in other portions of the eastern Carboniferous basins, as well as to establish a paleontologic section for comparison of local floras in the central portion of the Appalachian region. Although the work on the section is not yet completed, it is thought the facts ascertained are of sufficient interest to justify a preliminary publication.

So far as the discussion concerns other regions, the evidence considered will be mostly paleontologic and therefore chronologic.

\section{Rapid Differentiation of and Change in Floras during Pottsville Time.}

It should be remarked at the outset that wherever plants have been gathered from several horizons in thick sections of the Pottsville in different portions of the Appalachian belt, a careful scrutiny of the specimens shows a distinctly notable difference between the floras gathered at intervals of several hundred feet in the same section. Indeed, the period of change in conditions of environment attending the transition from Lower Carboniferous marine to true Coal Measures formation was marked by an extraordinarily rapid development and modification of vegetable species. Within a relatively short period the meager flora of the Devonian and Pocono is multiplied to the inexhaustibly fecund and highly diversified flora of the Carboniferous, a development scarcely possible except in this division of organic life, which is the most sensitive to climatic change or environment, excepting perhaps the higher vertebrates. In the lower part of the Pottsville series many species show a relation to the floras of the Vespertine or Calciferous Sandstone series; in the middle portion many of the forms are unique, while in thickly developed sections it is only near the top of the series that we see occasional Coal Measures forms creeping in.

These modifications and differentiations of forms have been found to be fairly consistent and generally constant in their relative position in the various sections thus far examined. This is true even of those very distant, but because the modification of a plant from one stage to another, though representing a definite phase or form, is often not sufficient to constitute a distinct species, and because these stratigraphic modifications of species have received little or no attention in our American literature on Paleozoic plants, I shall frequently be obliged to refer to them as forms, designating them by the name of some locality or well 
established horizon in which they have so far been characteristically or predominantly found.

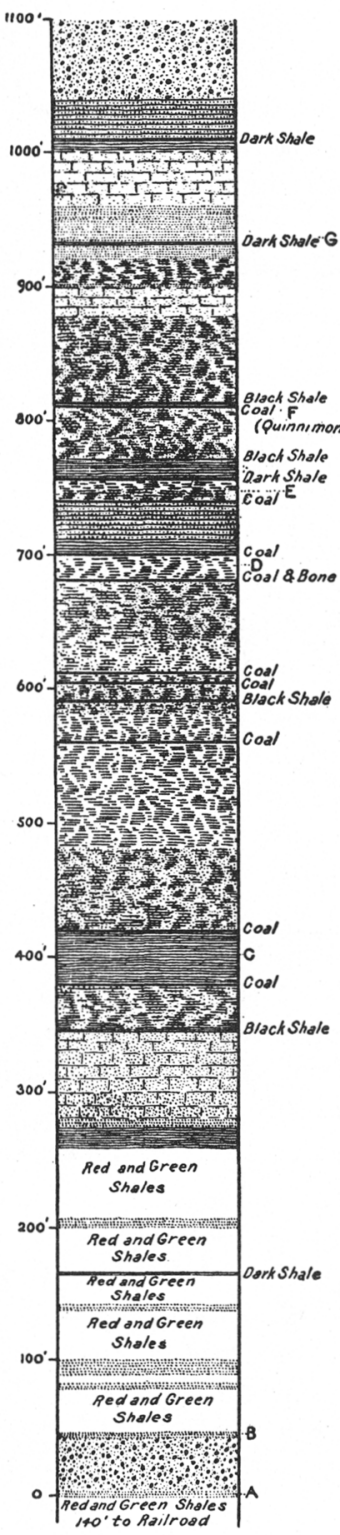

Figure 1.-Piney Creek Section.

\section{Stratigraphy of the Series.}

GENERAL STATEMENT.

Before introducing any paleontologic facts it will be necessary to present their proper stratigraphic setting. Accordingly, while it is not my province to discuss the stratigraphic equivalents of the individual beds in other Appalachian sections, I give here two sections which show the series as a whole, the position of the mined coals and the beds from which plants were obtained.

\section{CONGLOMERATES OF PINEY CREEK SECTION.}

The first section (see figure 1), that along the road up Piney creek, about two and one-half miles below Princes station on the Chesapeake and Ohio railroad (chosen because it is the type section described by Professor Fontaine), is one of the most complete along the river, though badly weathered, and consequently appearing much less arenaceous than other sections up the walls of the gorge.

The two conspicuous bench marks of the sections along this portion of the river are the massive conglomeratic sandstones at the top and near the base of the declivity. The lower one, frequently more or less calcareous, is a conspicuous feature of the gorge of New river in the vicinity of Mill creek, Quinnimont and Princes, where enormous blocks, which at first sight resemble those so abundant in the neighborhood of Nuttall and Fayette, have fallen into the river. Although the calcareous red and green shales extend nearly 200 feet higher un, this lower conglomerate was made the base of the "Conglomerate series" as originally defined by Professor Fontaine. Though almost without partings in the region of Piney creek, it loses much of its massive conglomeratic individuality in passing down the river, where it becomes hardly distinguishable from 
other more or less conglomeratic sandstones at various horizons higher in the series. Largely to this fact, as well as to the irregularity and instability of the lower sandstones of the various sections and to a slight undulation of the strata, are probably due the differences of opinion still current respecting the number and equivalence of the coals worked along New river.

The upper member of the Piney Creek section, another massive conglomeratic sandstone, is now known to be quite distinct from the remarkable formation at the top of the Nuttall section correlated with the Homewood sandstone of Pennsylvania by Professor I. C. White. With the exception of the latter, this top Piney Creek sandstone is the most regular and persistent member of the entire series in this region, though its conglomeratic habit is somewhat variable. I have traced it quite clearly in more than twenty-five sections from Crow, about 9 miles southwest of Quinnimont, to near water level at Hawks Nest, where it forms the foundations for the railroad bridge across the river. Its massive conglomeratic ledge is the "table rock" at Table Rock post-office and defines the brow of the terrace plateau and river gorge for most of the distance down to Fire Creek. From its crest above Fire Creek mine there opens a superb vista of the gorge and terrace, extending to the northward, in which near Keeneys creek and Nuttall the "Homewood," about 400 feet higher, is seen to descend to complete the wall of Pottsville rocks which gradually declines to the falls of the Kanawha.

COMPLETION OF SERIES AT NUTTALL AND HAWKS NEST.

The continuation of the Piney Creek section up to the base of the "Homewood sandstone" is given (see figure 2)* from the Nuttall sec-

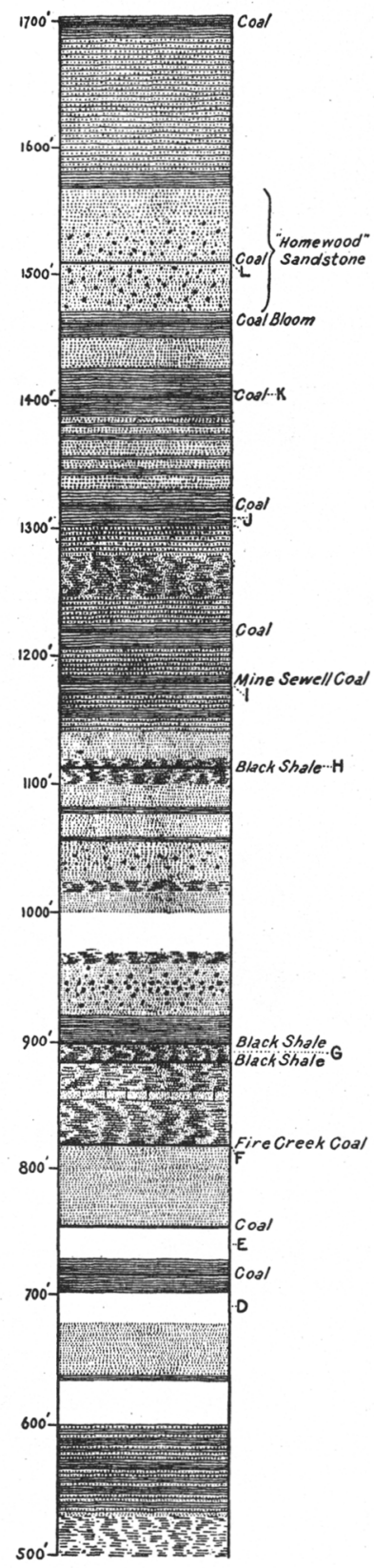

Figure 2.-Nuttall and Hawks Nest Section.

*'The accompanying sections are platted from the barometric readings at the specified localities. 
tion, which I have chosen because the series in this vicinity has been selected for description by Professor I. C. White**

The features of the "Homewood," which completes the Pottsville series, and the superimposed basal portion of the Lower Productive Coal Measures I have taken from the section at Hawks Nest.

The examination of a number of measurements indicates the thickness of the Pottsville series along New river to be approximately 1,600 feet, if we measure from the base of the lower conglomerate on Piney creek, the base of Professor Fontaine's "Conglomerate series," to the top of the Homewood, or about 1,300 feet if we follow Professor White in measuring from the top of the red and green shales, a result which agrees in the main with that published by the latter author.

\section{NUMBER AND POSITION OF COALS MINED ON NEW RIVER.}

A comparison of the sections, which were made at nearly every mine above Sewell, shows almost conclusively that along New river only two seams are mined in the Pottsville series. In fact, instead of finding that the operations cover two or three veins below the upper Piney Creek conglomerate, as has commonly been supposed, all the openings appear to be at the same horizon and in the same stratigraphic sequence-the Quinnimont coal being the same as the Fire Creek coal.

Although my sections of the series are barometric and were sometimes made under unfavorable conditions, they cover so many localities within a distance of about thirty miles along the river, and they are so remarkably harmonious in showing that the workable coals fall so closely within the same limits, as to establish a probability, so strong as to justify the assumption as a working hypothesis at least, that all the mines below the upper Piney Creek conglomerate are in the Quinnimont-Fire Creek seam, the mines between that conglomerate and the Homewood being confined to the Sewell coal. $\dagger$

\section{QUINNIMONT-FIRE CREEK HORIZON.}

In the Piney Creek section (see figure 1) I have marked as "Quinnimont "a coal having precisely the same position and local characters as that found in the mines on the Quinnimont seam in that vicinity. Its distance from the top of the upper Piney Creek conglomerate in this case is the same as that measured on Mill creek, at Quinnimont and Alaska, the stratigraphic association being exactly that at the Royal mine, near

* Bull. U. S. Geol. Survey, no. 65, p. 197.

+ So close, if not identical, are the Quinnimont and Fire Creek coals that a number of leveled sections will be required to fully establish their relations. Considering the circumstances of exposure and existing developments it seems improbable that two workable coals should be so close together in one section of this region without the discovery of both in the same section. 
Princes, two and one-half miles above. If my barometric sections are not erroneous, the same seam is worked at Beechwond, Stone Cliff (lower opening), Dimmock, Rush Run, Red Ash, Beurys and Fire Creek. Thus at the last named mines, which admittedly work the Fire Creek coal, the interval from the mine mouth to the top of the upper Piney Creek conglomerate falls within the same limits, approximately 295 feet, while the stratigraphic environment is the same as at Quinnimont, Princes and other mines unquestionably working the Quinnimont coal.

Among New River coals, as well as among Pottsville coals in other regions, there is much variation in the roof and in the thickness of the seams themselves. At Quinnimont and Mill creek good fossils are extremely rare; at Princes, Alaska, Fire Creek and Beurys a few fragments were obtained, while Stone Cliff and Red Ash approach the rich flora found at Dimmock and Rush Run. The increasing richness of the flora toward the apex of the long bend of the river near 'Thurmond suggests a better preservation of the plant remains toward the northwest or down the dip, though the latter circumstance may be merely coincident.

\section{POSITION OF SEWELL COAL.}

Measuring again from the top of that valuable bench mark, the upper Piney Creek conglomerate, my barometric readings show the mine mouths at Thurmond, Brooklyn opposite East Sewell, Cunard opposite Sewell, Nuttall, Fayette, Elmo and Hawks Nest to fall within a distance of from 55 to 85 feet, or approximately 75 feet. There is little room for doubt that the mines at these points are all in the same seam, best known as the "Sewell" or "Nuttall" coal. This coal (see $I$ of figure 2) is also exposed at Rush Run, about 70 feet above the upper Piney Creek conglomerate, or 365 feet above the opening on the Quinnimont-Fire Creek coal. The same seam is reached by tram in the knob back of Beurys, and again by the same method farther up the river, at Stone Cliff. Although no sections were made at the following points, it appears very probable that the mines at Slaters and Central are in the Quinnimont-Fire Creek coal, the operations at Caperton, Keeneys Creek, Gaymont and Sunnyside keing in the Sewell coal. Dr D. W. Langdon, whose geologic interpretations are well known to be reliable and who is especially familiar with the New River series, kindly informs me that the Loup Creek coal mines operate in the Sewell coal, a correlation with which the evidence of the fossils is quite harmonious.

From what has been stated above it appears that all the New River (Pottsville) coals now mined in this region come from two horizonsthe Quinnimont-Fire Creek horizon and the Sewell coal.

As indicating in a general way the direction of the strike, it may be 
noted that the coal outcrop and the upper Piney Creek conglomerate are respectively at nearly the same distance, barometric readings, above the Chesapeake and Ohio Railroad at Stone Cliff and at a point a little to the east of Beurys; so also at Rush Run and Cunard; or at the Thurmond mine and a point probably between Nuttall and Keeneys creek.

\section{Paleontologic Relations.}

\section{GENERAL STATEMENT.}

The general affinity of the plants collected by Professor Fontaine from the New River coals with those in the Sharon coal of Ohio has already been stated by Professors Fontaine and White. A portion of the material listed below comes from one or two of the former author's localities.

A preliminary examination of a collection recently made in the typical section of the Pottsville in the southern anthracite field of Pennsylvania and a comparison of it with that from New river shows that the floras are essentially the same, they being largely identical in the corresponding portions of the sections. In other words, the plants found in the greater portion of the "Conglomerate series" on New river are Pottsville plants and belong to stages represented in the Pottsville section of Pennsylvania. I have found the same to be true of the Great Flat Top Mountain and Tug River sections farther south.

\section{FOSSILIFEROUS HORIZONS.}

Before proceeding further it is best to pass briefly over the localities from which plants were obtained, referring at the same time to the stratigraphic position of the fossiliferous beds in the accompanying figures.

The lowest beds from which plants were gathered are the strata immediately above and below the Piney Creek conglomerate, comprising the base of Professor Fontaine's "Conglomerate series" (see $A$ and $B$, figure 1). Scanty material was gathered from these beds on Piney creek. Numerous fragments, poor in species, were gathered from or near an horizon about 370 feet above this conglomerate on Piney creek, at the mouth of Arbuckle creek, and near Rush Run (see $C$, figure 1). Specimens were collected at from 60 to 100 feet below the Quinnimont-Fire Creek coal on Mill creek, Piney creek (see $D$ and $E$, figure 1), and at Nuttall (see $D$ and $E$, figure 2). The Quinnimont-Fire Creek coal plants came from Quinnimont, Princes, Alaska, Beechwood, Stone Cliff, Dimmock, Rush Run, Beurys, Red Ash, Fire Creek (see $F$, figure 1), and Nuttall (see $F$, figure 2). Fossils were gathered at an horizon, about 100 feet higher, at Crow post-office, on Mill creek, and on Loup creek (see $G$, figure 1), and at Nuttall (see $G$, figure 2). Above the upper Piney Creek conglomerate 
and below the Sewell coal fossils were found at Turkey Knob and Hawks Nest. From the Sewell coal plants were collected at Stone Cliff, Turkey Knob, MacDonald, Thurmond, Brooklyn, Cunard, Nuttall and Hawks Nest (see $I$, figure 2). Plants were found at several horizons between the Sewell or Nuttall coal and the base of the "Homewood sandstone" at Nuttall and Hawks Nest (see $J$ and $K$, figure 2). At the last named locality a little material was dug from a parting in the Homewood itself (see $L$, figure 2). These were the highest plants collected from the Pottsville series. Some material was obtained from a coal in the Lower Productive Coal Measures, or "Alleghany series" of I. C. White, a short distance above the Homewood sandstone.

FOSSIL PLANTS NEAR THE LOWER CONGLOMERATE ON PINEY CREEK.

As it is not my purpose in this paper to attempt any local or detailed paleontologic correlations, I shall consider only the plants obtained from a few of the richer or more interesting horizons.

The identifications are preliminary, and many of the names, for reasons stated at the beginning, are, pending revision or description, merely tentative and subject to change.

The shales immediately above and below the lower Piney Creek conglomerate, which, like portions of the conglomerate itself, are more or less calcareous, are poor in plants. From those at the base (see $A$, figure 1) I obtained:

Sphenopteris subgeniculata, (Stur.) Schütze (?).

Sphenopteris cf. decomposita, Kidst.

Asterophyllites, sp. indet.

Sphenopteris subgeniculata is one of the European Culm species, while S. decomposita is found in the Calciferous Sandstone series of Scotland.

From immediately above this conglomerate (see $B$, figure 1 ) were obtained :

Adiantites, sp. smaller than antiguus, (Ett.) Stur.

Sphenopteris, sp. extremely lax.

Sphenopteris distans, Stb.

Asterophyllites cf. minutus, Andr.

Carpolithes, small.

Rhabdocarpus, n. sp.

Here again those acquainted with Paleozoic fossil plants will recognize a general Lower Carboniferous cast, though the forms are few. Sphenopteris distans is a true Culm species, being one of the characteristic plants of the Hainichen-Ebersdorf Culm and the roofing-slates of Moravian Silesia.

About 150 feet of largely calcareous red and green shale and sandXLIV-Bub. Grol. Soo. Ax., Vor. 6, 1894. 
stones overlie the lower conglomerate, all of which are excluded from the "Pottsville" as restricted on New river by Professor I. C. White. In connection with this fact it may be noted that, while on New river the transition from marine to coal measures sedimentation is very much more gradual than in the Pottsville basin in Pennsylvania, it is marked by a much stronger contrast and evidence of change than is apparent in the Great Flat Top Mountain section. This section, while nearly destitute of conglomeratic material, presents an essentially arenaceous and quite frequently phytiferous series, with occasional coaly layers, as far down perhaps, if there is no unconformability, as the horizon of this lower Piney Creek conglomerate. This circumstance will be referred to later in relation to certain Appalachian evidence tending to show that the base of the Pottsville series (lithological) diagonals in time.

POCAHONTAS COAL ON NEW RIVER.

One of the most interesting stages in the New River section is the next higher level at which plants were found. In shales associated with a thin coal (see $C$, figure 1) nearly 700 feet below the top of the upper Piney Creek conglomerate, or about 400 feet below the Quinnimont coal, a few species are common at Piney creek, at the mouth of Arbuckle creek, and near Rush Run. They are the following:

Sphenopteris, n. sp., Pocahontas form.

Neuropteris smithsii, Lx., Pocahontas form.

Rhabdocarpus, sp., Pocahontas form.

Alethopteris, sp.

The fact that the first three of these are predominant in and characteristic of the Pooahontas coal in Great Flat Top mountain and have not been found to extend far above or below that horizon led me to regard this stage, from paleontologic evidence, as equivalent or near to the Pocahontas coal, an opinion which has since been corroborated on the stratigraphic side by Mr M. R. Campbell, who has traced the strata from Tug river, about 60 miles away, across to New river.

FLORA OF THE QUINNIMONT-FIRE CREEK STAGE AND ITS AFFINITIES.

Without stopping at this time to discuss the paleontologic details of other intermediate horizons we will pass to the consideration of the general affinities of the fossils from the important coals. To concentrate the data as much as possible the species obtained at various localities from the Quinnimont-Fire Creek coal* are tabulated in one list. The

- While the equivalence of the Quinnimont and Fire Creek coals is, as I have said abore, aot conclusively proven, they are certainly so near together, if not the same, that in a broad consideration, dealing with groups, they may be treated as at one stage. 


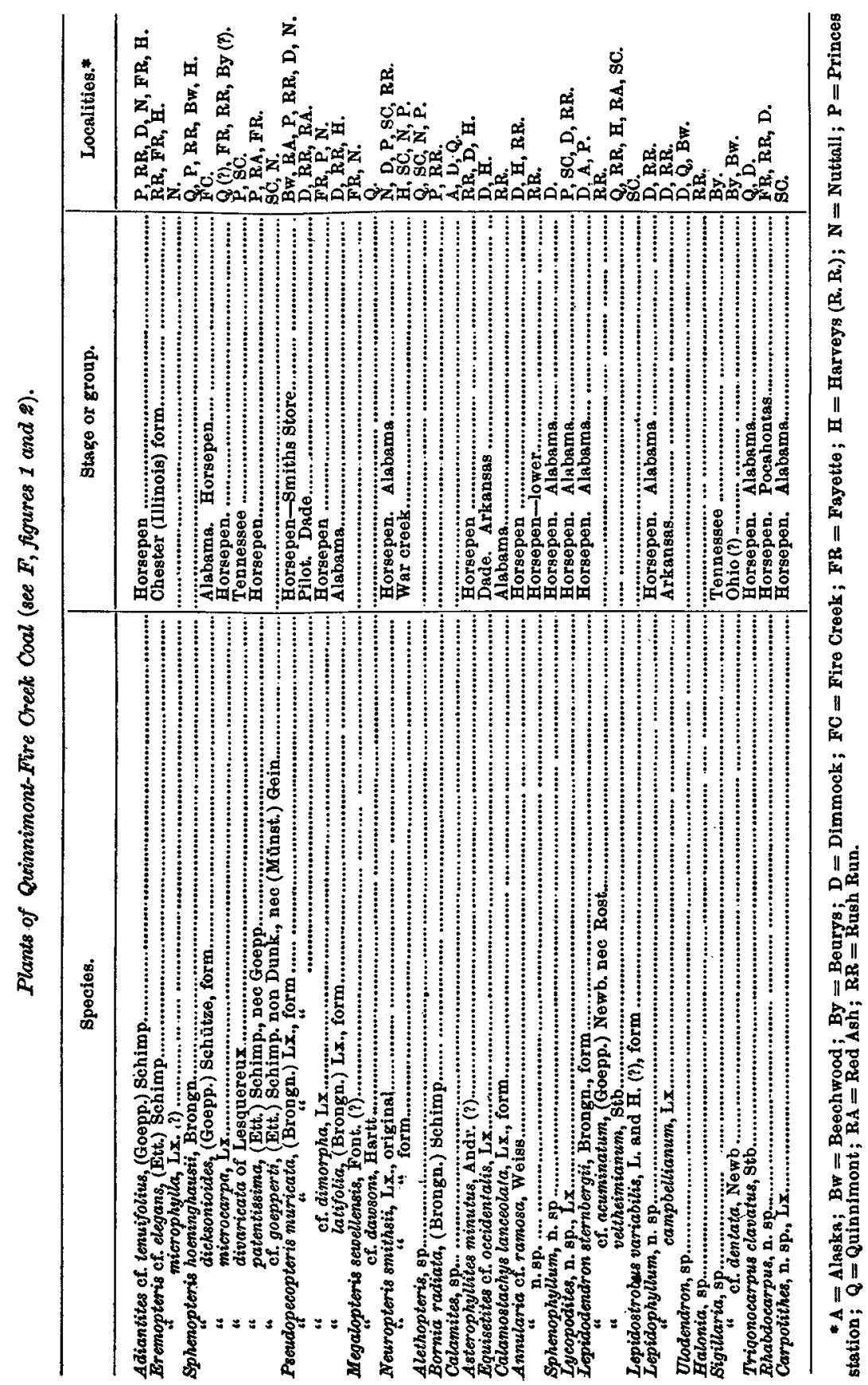


second column refers to stages or groups in the Pottsville sections in Pennsylvania, Ohio, Tennessee, Virginia, Arkansas and. Alabama. Thus "Ohio" indicates the Sharon coal in Ohio; "Ark." is used for the "coalbearing shale" of Washington county, Arkansas, the flora of which is found to be largely identical with and clearly belonging to the Sewanee group of Tennessee, indicated by "Tenn." "Horsepen" is used for present convenience, without any intention to add to geologic nomenclature, to indicate a group of coals above the Pocahontas coal in the lower half of the Pottsville sections of Tug river and Great Flat Top mountain. They are more or less exposed near the school-house at Horsepen, near the fault-line at Smiths Store, near the mouth of War creek on Dry fork, and in Clarks gap on Great Flat Top.

A brief inspection of the second column in the accompanying tabulation shows that nearly one-half of the varieties or forms collected from this stage are characteristic or predominant in the lower middle portion of Tug River section, while a third of the entire number are either of too great a vertical range to possess any precise correlative value or they have not been noted by me from any of the other sections yet examined. Considering, then; only those species, forms or phases of species which have thus far been observed to be limited in their ascent and to be characteristic of certain horizons or groups, it becomes at once obvious that the great preponderance of the forms of this particular stage is also found in and mostly characteristic of the group represented at Horsepen and near Peeryville, in the Tug River basin, at Smiths Store, and at Clarks gap, on Great Flat Top mountain.* Several of the forms are more characteristic of higher stages, such as the Sewanee group in Tennessee and Arkansas and the Sharon coal of Ohio, while a few come from horizons whose comparative paleontologic stage is not yet known to me.

\section{FLORA OF THE SEWELL COAL AND ITS. RANGE.}

Treating in the same way the plants obtained from the Sewell coal at various localities, it appears that nearly three-fourths of the forms are characteristic of the Sewanee group in Tennessee, which includes the "coal-bearing shale" of Washington county, Arkansas, and to which probably belongs the flora of the Sharon coal in Ohio. At all the localities along the river the plants $\dagger$ gathered from the Sewell coal are at once

* It requires no extensive study of the floras of the coals at Horsepen and Smiths Store-both localities concerning which there has been much doubt and difference of opinion on account of their being more or less isolated and against the fault-line-to show their intimate relation and identity with those between Jacobs creek and Peeryville, on Dry fork, or in Clarks gap.

$\dagger$ It should be borne in mind that, as remarked at the beginning of this paper, I treat as forms, often less than varietal in rank, those variations of species which appear, so far as the study of the Potisville floras has extended, to have been much restricted in time, and seem therefore tolerably characteristic, at least locally, of fairly definite stages or groups. 


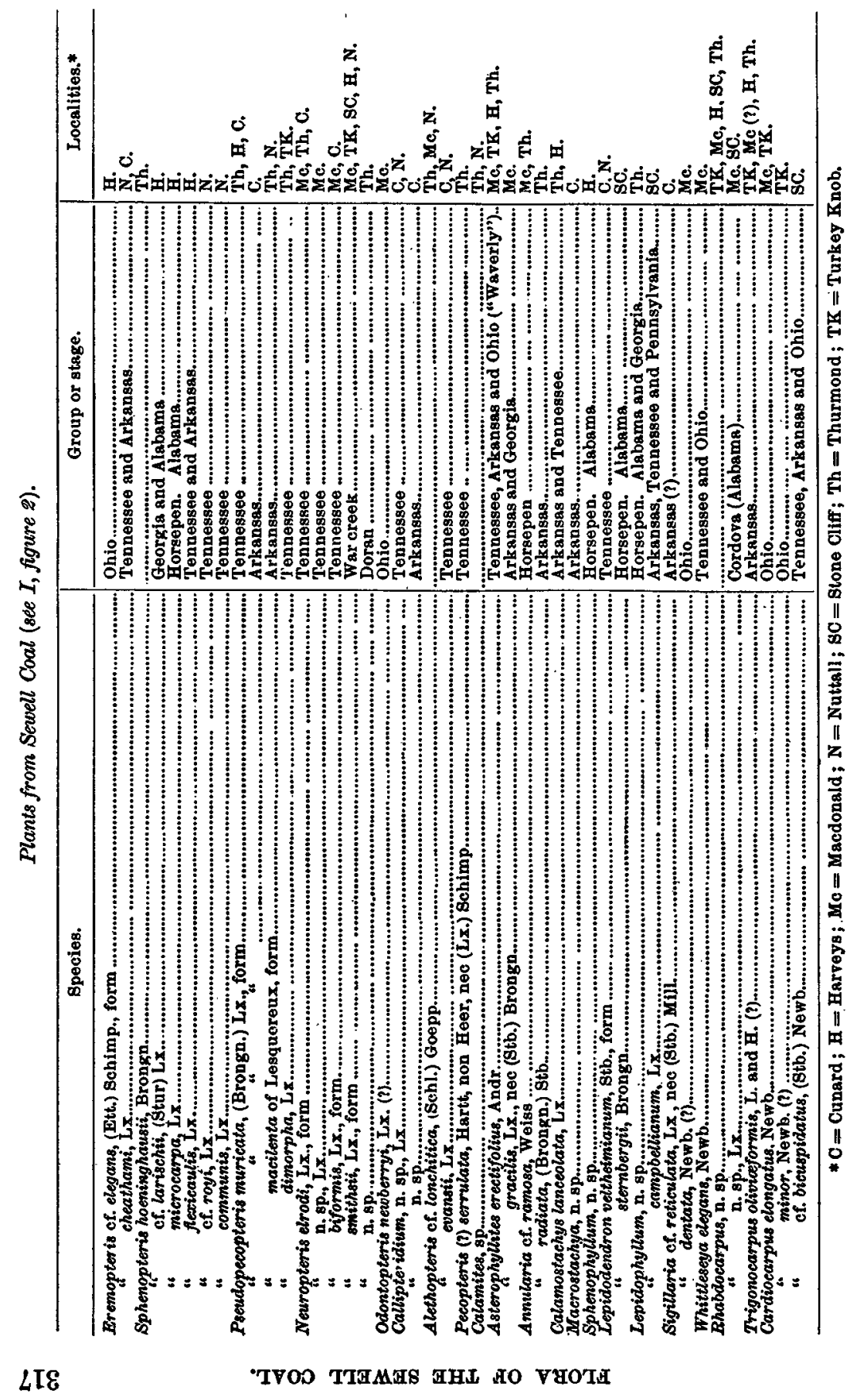


seen to be closely related to the flora of the main Sewanee coal of Tennessee and of the "coal-bearing shale" of Washington county, Arkansas. The material from the Cunard mine, opposite Sewell, is astonishingly similar in most respects to that found at. Rockwood or Tracy City, in the former state.

While the paleontologic evidence makes it reasonably certain that the Sewell coal was formed at a time relatively near that of the main Sewanee coal, the inference that they may be the same coal is far from demonstration. Only those who have a strong predisposition to discover the continuity of individual sandistones or coals throughout the Appalachian basin will, possibly, anticipate from this evidence, perhaps largely circumstantial in character, that the two valuable coking coals are the same, the "Emory sandstone" above and the "Sewanee conglomerate" below the coal in Tennessee being equivalent to the Homewood and upper Piney Creek conglomerate respectively in the New River section.

FOSSIL PLANTS OF THE "HOME WOOD SANDSTONE."

One other of the plant beds in the New River section deserves mention, since its paleontologic affinities will serve as an additional illustration in the evidence touching upon the relation of the "Pottsville" of Ohio to that of the central Appalachian region.

From a parting in the Homewood sandstone (see $L$, figure 2) in the vicinity of Anstid fragments of the following flora were gathered:

\section{Plants from Homewood Sandstome (see L, figure 2).}

Species.

Stage or group.

Archropteris, n. sp., related closely to ...... Ohio and Pennsylvania.

Eremopteris, sp...................... Ohio.

Sphenopteris furcata, Brongn.............. Ohio, Pennsylvania and Coal Measares.

Sphenopteris cf. divaricata of Lesquereux, form. Tennessee.

Pseudopecopteris cf. acuta of Lesquereux..... Coal Measures.

Neuroptiris, sp..................... Ohio and Coal Measures.

Odontopteris gracillima, Newb............. Ohio.

Alethopteris cf. ambigua, Lx............. Coal Measures.

Cardiocarpus bicuspidatus, (Stb.) Newb...... Ohio, Arkansas and Pennsylvania.

Trilktes, sp.

A glance at the above list shows that we have here to do with a flora the preponderant elements of which are characteristic of the Sharon coal of Ohio. One of the species, a form identified by Professor Lesquereux as Sphenopteris divaricata, is characteristic. of the Sewanee stage of Ten- 
nessee, though I have rarely seen it from a higher horizon. Several of the species belong properly to the Lower Productive Coal Measures.

\section{PALEONTOLOGIC RELATION OF NEW RIVER SECTION TO SHARON COAL IN OHIO.}

This flora is not presented as proof that it represents the horizon of or is synchronous with the Sharon coal in Ohio. It illustrates a fact observed in every section of the Pottsville yet examined, namely, that in the thick sections of this series the plants of the Sharon coal are found only in the upper part of the section, and that, though straggling forms begin to appear near the middle of the series, we do not find the association of species characteristic of the Sharon coal to prevail and stand forth predominantly until we near the top of the series. In every case the paleontology of these greatly thickened sections of the Pottsville shows the stage of the Sharon coal to be in the upper half of the series and relatively high therein. Although its fossils relate it closely to the Sewanee of Tennessee and the coal-bearing shale of Washington county, Arkansas, even allowing for a higher range of the species in passing southward, it can hardly be older than the main Sewanee, while there is some evidence that it is more recent. I can find no satisfactory paleontologic support for the view * that "this Sharon bed and its thin rider appear to represent all the coals in the New River group."

\section{Equivalence of Potrisville Sections.}

The foregoing paleontologic evidence has a direct bearing on the important question of the equivalency of the various sections of the Pottsville in the different portions of the Appalachian basin. The opinion seems generally to prevail that the time covered by the Pottsville series in the various portions of the Appalachian trough is the same, or very nearly the same, and that the very thick sections simply represent expansions of some or all of the members present in the thin sections. Thus Professor I. C. White, in his invaluable bulletin on the stratigraphy of the bituminous coal field, $\uparrow$ argues that the Virginia-Kentucky section, 2,000 feet or more in thickness, represents an expansion of a series never over 300 and sometimes less than 200 feet thick in Ohio. If this be true, then the lower 1,500 feet, in round numbers, of the southern section must cover the time represented by the "Sharon conglomerate," a formation only from 20 to 40 feet thick, or even wanting in places, in Pennsylvania and Ohio. On the contrary, the evidence of the

* See I. C. White : Bull. U. S. Geol. Survey, no. 65, p. 202.

† Op. cit., pl. ii, fig. 2. 
fossils, so far as yet observed, gaes to show that, although members of the thin sections are usually much expanded in the thick sections, still the greater part of the increase is due to earlier sediments underlying the equivalents of the thinner sections and lithologically belonging to the same series.

In general, it may be said that, so far as the fossils have been gathered and studied (including those from the type section of the Pottsville in the southern anthracite basin), those from the thin sections are found in the upper portion of the thick sections, those of the moderately thick sections being present in about the same interval, measuring downward, in the much thicker sections, while those from the basal portions of these thicker sections are more or less unique and still farther removed from the flora of the Lower Coal Measures.

The floras of the middle of the very thick sections of the Pottsville appear to be largely identical with and to present the general facies of the Ostrau-Waldenburg floras of Moravian Silesia, while those from the base of the sections have much in common with the Culm or Carboniferous limestone series of the old world.

\section{Problem of Correlation of Base of Pottsville Series.}

The facts that (1) along the northern rim of the Appalachian coal field and in the Mississippi Valley states the rocks (Pottsville) between the true Coal Measures above and the Lower Carboniferous series with marine fossils below appear to carry only the fossils of the upper portion of the moderately thick and very thick Pottsville sections, seeming really to be equivalent, practically, to only the corresponding portions, measuring downward, of the thick sections, and (2) the increasingly unique and ancient character of the lower flora in the very thick sections, stand in evidence to show either that there is a time-break between the base of the thin section and the top of the Lower Carboniferous, which break should represent at least the time required for the deposition of the greater portion of the thick section, or that the thick section of the Pottsville overlaps in time the Lower Carboniferous in the northern and Mississippi Valley states, the floras of the lower portions of the thick section being in the latter case contemporaneous with marine invertebrates in the Lower Carboniferous of the central states. This problem, as well as the consequent question of the propriety of including the entire Pottsville series or "Conglomerate series" of the southern Appalachian region in the Upper Carboniferous, may be considered to better advantage when the examination of the material from the very thick section of eastern Kentucky and from the southern anthracite field of Pennsylvania is completed. 